\title{
Election Gifting and the Ordeal of Democracy in Nigeria
}

\author{
Adeagbo A. Adekola \\ Department of Culture and Social Sciences, University of Osnabrueck, \\ Germany \\ Omodunbi O. Olumide \\ Department of Political Science, Osun State University, Osogbo
}

Doi:10.19044/esj.2019.v15n5p119

URL:http://dx.doi.org/10.19044/esj.2019.v15n5p119

\begin{abstract}
Over-time, researchers have failed to show how citizens share, if not all, a part of the blame in Nigeria's failing democracy. Through election gifting, the community of voters in Nigeria have been selling their commonwealth to politicians who should not be anywhere close to power. Using secondary sources of data and relying on Robert Dahl's theory of democracy, the paper argues that since the people are the custodians of the political mandate in any democracy, they should be held accountable when there is a problem. The paper further identifies the history, effect, scope, and predisposing factors of election gifting in Nigeria. This paper focuses on the fact that the non-evaluative and clientelist approach to democracy are the reason for the sad realities in Nigeria and concludes that only the engagement in a civil society can revive Nigeria's failing democracy.
\end{abstract}

Keywords: Clientelist, Commonwealth, Election gifting, Democracy, Nigeria

\section{Introduction}

The concept of "vote buying", or what some scholars refer to as "money politics" in Nigeria has continued to play a dominant role in determining who wins an election from the second republic of 1979 (Ojo, 2008, p.113-115; Lucky, 2013, p.6). Representative democracy, which is a system of choosing individuals that speak and act on behalf of the people through a free and fair election process, was first introduced in Nigeria in the year 1999 (Inokoba \& Kumokor 2011, p.142-143; Animashaun, 2015, p.186). Since then, Nigeria has continuously witnessed an uninterrupted democratic rule under the principle of holding periodic elections (Animashaun, 2015, p.186; Inokoba \& Kumokor, 2011, p.143). However, the concept of 
democracy is not limited to holding periodic elections alone, but it also takes into account the process through which candidates, political parties, electoral institutions, and citizens follow and adhere strictly to the rules of the game. This takes a candidate from the period of contesting for electoral position, to the time where he/she receives the mandate to exercise state powers regarding affairs that are related to the elected capacity (Dahl, 1998, p.38; Alapiki, 2004, p.130; Alemika, 2007, p.1; Inokoba \& Kumokor, 2011, p.140; Huntington, 2016, p.239-240). These among other concepts such as legitimacy, good governance, and civil society have continued to expand the mirror through which democracy is viewed within the academic community (Diamond, 1994, p. 4-5; Rothstein, 2013, p.3-4; Huntington, 2016, p.239).

Nigeria can be classified among the young democracies of recent time with just 18 years of uninterrupted democratic existence since 1999. This practice of democracy so far, cannot be said to be void of problems and challenges especially during and after electoral proceedings. The problems over time have been discussed by scholars in the field of political science and other social science related disciplines. Some of these problems involve: stealing of ballot boxes, multiple registration of voters, manipulation of electoral rules and processes, election rigging, vote buying, political assassinations among other institutional issues blamed on the electoral body in Nigeria (Ugoh, 2004; Danjibo \& Oladeji, 2007; Alemika, 2007; Ojo, 2008; Sha, 2008; Lucky, 2013; Animashaun, 2015). Furthermore, the consequences of these challenges have continuously affected the democratic progress of the Nigerian state. This is because since good leadership is the foundation of every progressive democracy, the defective system practiced in Nigeria cannot guarantee the true dividends of democracy (Diamond, 1994; Alemika, 2007; Ojo, 2008; Amadi, 2011; Rothstein, 2013; Onapajo, 2015; Animashaun, 2015).

While many scholars try to engage theories and concepts to explain the problems facing the Nigerian democratic system, the problems have continued to grow with little or no improvement. In principle, when a faulty process brings candidates into power, the delivery and expectations cannot be more than the initial defective input (Diamond, 1994; Rothstein, 2013; Ojo, 2008; Alapiki, 2004, Onapajo, 2015). The result of the system practiced manifests itself as the many problems facing the Nigerian state today such as: corruption, economic hardship, unemployment, ethnic conflict, insecurity, and terrorism. Thus, these are some of the challenges that continue to manifest itself in the Nigerian polity.

Furthermore, many people including scholars at this point find it easy to blame various institutions of government and politicians without looking at the direction of those people (the citizens) who elect these politicians as part of the problem. Moreover, scholars often identify the existence of "vote 
buying" and the interplay of money and election gifting in Nigerian politics. They easily show scholarship by analyzing the scope of its existence, but fail to realize that members of the society (citizens), who collect money and gift items from politicians, are also part of the problem (Schaffer \& Schedler, 2005; Alemika, 2007; Danjibo \& Oladeji, 2007; Bratton, 2008; Ojo, 2008; Sha, 2008; Amadi, 2012; Inokoba \& Kumokor, 2011; Lucky, 2013; Animashaun, 2015; Onapajo, 2015). The issue of vote buying however does not show the justification why citizens sell their conscience, but there is a realization that democracy in its true sense cannot be made to function in such manner if its dividends are expected to be seen in the Nigerian state. Using secondary source of data gathering and content analysis, this paper will examine election gifting and the ordeal of democracy in Nigeria and offer suggestions on how Nigerians can refrain from engaging in election gifting in the demand and fight for good governance.

\section{Conceptual Clarification}

Schaffer and Schedler (2005, p.5) and Simeon Nichter (2014, p.315) argued that the idea behind the definition and understanding of "vote buying" is problematic. They identified in their work the contrasting usage of the term "vote buying", and how it sometimes fails in the context it tries to explain. Furthermore, it will be worthy to stress that political scientists sometimes make mistakes in the development and understanding of concepts such as the case of vote buying, which in its usage, does not cover in full terms the true meaning of what it seeks to explain. It falls into the category of what Satori (1970) cited in Nichter (2014, p.315) as "conceptual stretching".

Schaffer and Schedler (2005, p.3-6) explains the idea of "vote buying" as a simple economic exchange, where candidates "buy" and citizens "sell" their votes. However, when this particular trade happens, it does not only involve the use of money, but also the use and distribution of other materials such as: food stuffs, clothes, electronic gadgets, recharge cards, motor bikes, vehicles among other things, which in this case limits the use of the word "buy". To "buy" according to the Longman dictionary of contemporary English, it literally involves the conscious use of money to pay for a particular commodity or service between two agreeing parties (Procter, 1978). However, in this case, the circumstances are different as most politicians never come bearing gifts with the intention that they are buying the votes and the conscience of the citizens. They (politicians) come under the pretense of alleviating poverty and contributing to the economic development and lives of the people. Therefore, vote buying does not happen under any legal contract to prove that a particular commodity was bought or sold, and in turn an obligation to fulfill such particular bargain on the part of the seller (citizens) is made. 
To this point, "election gifting" tends to be the idea political scientists try to explain, when they use the word "vote buying" in the Nigerian context, where money and materials such as food item etc. are distributed during campaigns and on Election Day. The justification for this claim is that a gift can come in form of cash or materials, and there is also no statute that binds one who receives a gift on how he/she is supposed to react during or after the said gift has been collected, like in the case of when something is bought. In the same vein, there is also no legal obligation whatsoever, holding one from not delivering on the terms, in which such gifts are given, especially when they are not spelt out like in the case of when something is bought, for the exchange of goods or services. Significantly, there is also no measure through which one can know, if a particular citizen or voter in this case, voted for the said candidates under the democratic principle of secret balloting that could show compliance (Shaffer \& Schedler, 2005, p.6). Therefore, it is in its broad sense that "election gifting" seems to cover most conceptual lapses "vote buying" fails to cover. This is why it is preferably used in this paper.

\section{Theoretical Framework}

This paper relies on Robert Dahl's (1956) theory of democracy in analyzing the practice of democracy. Dahl opined that democracy shares a continuous linkage to good governance when the tenets of democracy are strictly adhered to. However, much injustice has been done to the idea of democracy in Nigeria and it has been further abused with no concern to the true meaning of what it stands for in its principle. Obasanjo (2005) argued that when democracy is practiced in the way it is practiced in Nigeria, ordinary people in the society will suffer and such is the reality today in the Nigeria state. Dahl (1989) gave the following arguments in his framing as the implication of having a true democracy:

- Equality of Vote: Dahl explains that in any democracy, every individual should have equal opportunity to vote, such that: the vote counts on a one man, one vote basis. This means that no one has any superior vote than another, and to that extent equality is dominant.

- Effective Participation: Democracy to Dahl without effective participation is no democracy. Adequate and equal opportunities of individual, groups etc. in expressing their preferences and opinions are uncompromising attributes of democracy. Dahl argued further that the contribution of members of the state should be done throughout the process of decision making.

- Enlightened Understanding: Dahl argues that a democratic society should be seen as a market place of ideas, where free speech and liberty is tolerated and allowed. Questions to provide enlightened understanding should be asked, such as: "does one person or group control the whole flow 
of information? Are multiple viewpoints on any topic available? Are there ways through which democracy can be said to exist in any country?

- Citizen Control of Agenda: Dahl emphasizes here the need for collective and equitable control of policy agenda by the members of the society such that; one person or group of persons does not have a disproportionate influence on the state policy and agenda. He opined further that the control of government should be embedded in community wishes, and these wishes should be the responsibility that the government is expected to hold important. In this aspect, issues like influence of money in politics and corruption are frowned at and widely unacceptable.

- Association Autonomy: Freedom to organize political parties, interest groups, and social movements are liberties that Dahl emphasizes should not be compromised in any true democracy. Diamond (1994, p.7) citing Dahl, also explains how the creation of such groups help to bring about balance and engagement of government in democratic societies.

- Inclusion: Dahl argues that societies should also take into cognizance the right of the minority. This can be done by asking questions that ensures the inclusion of everyone. E.g. does the society include and give rights to all the people, especially minorities within the polity? Dahl believes that the minorities should not be left out in democratic societies.

From the above analysis of Robert Dahl's theory of democracy, we can see how democracy shares a direct linkage to good governance as the end result of its process. The idea behind the concept of good governance in its relationship to democracy is not far from the fact that democratic societies around the world can only experience good governance when people stay true to the ideals of democracy. Furthermore, the ordeal of democracy in Nigeria cannot be said to be as a result of a failed system alone, but that of a failed people because the system itself is a construct of the people. However, the people have more power over the system because they form the system, and they decide the future they want by having indeed, a free and credible election void of election gifting.

Significantly, election gifting does not have a place in democracy, and the effect of election gifting in Nigeria is why the country continues to wallow in poverty, illiteracy, unemployment, and insecurity among other structural problems affecting the state. When politicians come bearing gifts, it should be expected that the said gift would come back to hunt the citizens as Obasanjo (2005) argued that the end result will be the ordinary people suffering. Blaming the government, whose setup was based on a faulty and defective foundation, for not performing its duties in this case is like fetching water into a basket. This is because both parties share parts of the blame, which would in turn question the legitimacy of the citizens' claim when they point accusing fingers to the politicians at the helm of affairs for not fulfilling 
their obligation. More so, the people (citizens) placing burdens on politicians, to give gifts and also collect the gifts when they are meant to discuss issues and ideas through which the lives of the populace would be better is against the tenets of democracy.

Lindberg and Morrison (2008) cited in Animashaun (2015, p.188) argued in their writing on the evaluative and the non-evaluative perspective of voting behavior. In this aspect, the Nigerian voter falls into the nonevaluative bracket with evidences of election gifting as avenues of winning voter's conscience. It is however worthy to note, that good governance in any society comes into place when the democratic foundation is uncompromising to factors that question the legitimacy of the people.

With opinions on how true democracy from Dahl's typology leads to good governance, Pipa Norris $(2008$, p.16) in his worldwide good governance measurement indicates that factors such as: the voice of the people and accountability, political stability and absence of violence, government effectiveness, regulatory quality, rule of law, and the control of corruption should become domicile in a country where true democracy is practiced.

Furthermore, we cannot deny the influence of the 2015 presidential election in Nigeria, which is one of the motivations to writing this paper in the wake of the 2019 election. At least for once, the people in Nigeria voted based on issues affecting the state, and not just on the gifts given by politicians. This was reported by scholars who took part in the 2015 elections, as well as those who researched into the issues, that led to the incumbent president losing to the opposition, for the first time in Nigeria (Abutu \& Samsu, 2017). By the above statement, this paper does not suggest that election gifting did not happen in the 2015 presidential election, but that the sharing of gifts did not play any major factor in influencing the massive support the people gave to the winning party, unlike the previous elections in Nigeria. The following issues were mentioned as part of the reasons why the then incumbent president was voted out: corruption, fractionalization of the Peoples Democratic Party (PDP) after the Nigerian Governors forum election in 2013, decamping of members of the PDP into the All Progressive Congress (APC), personality and track records of the candidates, the "change" campaign slogan of the APC, economic hardship, personality clashes between the then president (Goodluck Jonathan) and major stakeholders like Rotimi Amaechi and also former president Olusegun Obasanjo, imposition of the Jonathan candidacy without a primary election and lastly, the Boko-Haram insurgency and the kidnap of over 200 Chibok girls in the Northern part of Nigeria (Abutu \& Samsu, 2017; Araba \& Braimah, 2015; Babatunde, 2015; Adeolu, 2015; Udu, 2015). 


\section{The Evolution of Election Gifting in Nigeria: A Historiography}

In order to understand the historical evolution of anything in the Nigerian political sphere, it is always safe to trace the history from the different eras, from which the Nigerian states has existed. They are: the precolonial, colonial and the post-colonial era (Ojo, 2008, p.113; Deji, 2013, p. 84).

Starting from the pre-colonial era, there is no detailed account on the existence of election gifting because the system of government we had in this period was mainly monarchical. According to Ojo (2008, p.113), people got into position of power through: Hereditary blood lineage of the king, being a member of a royal family, and also being chosen or appointed by the gods. Other methods that existed then were through gerontocracy, or the age-grade system that existed in eastern part of Nigeria (Deji, 2013, p. 84). Although items and gifts could be given to kingmakers to show honor or pay homage. However, it was never done to influence an outcome as it was duly checked by the gods with consequences, such as: death or afflictions bestowed on the people (Ojo, 2008, p.113).

The colonial period, which in this case refers to the eve of Nigeria's independence, was also not different from what was witnessed in the precolonial era with little or no influence of money due to the following reason:

1. There were limited political parties available during this period.

2. The political parties then were operating under the supervision of the colonial masters, who monitored the process and avoided malpractice.

3. The colonial economy was agrarian, and there was not much influx of money in politics. This was because the strategies employed then, was the use of charisma to canvass for votes based on the ethnic and religious affiliations of the people.

4. The system bequeathed to Nigeria then, was a parliamentary system, which was less expensive, and it required a lesser number of people in politics (Ojo, 2008, p.113).

More so, the zero-sum game and competitiveness in today's politics was not rampant then, as the value of money was high and much influx of money as we have today was not in existence during the colonial period (Ojo, 2008, p.114). The existence of tribal heroes also limited the influence of money, as the tribal heroes controlled ideologically, with ethnic and religious sentiments, the political space of their various regions. As a result, this limited the influx of money as a determining factor. Politicians then, according to Ojo (2008, p.113), mainly distributed T-shirts with party emblems, and other materials used for the purpose of the election with no regard to how much they could offer to voters. 
Furthermore, an independent Nigeria in 1960 gave birth to more political parties, and the competition became stiffer and bigger (Ojo, 2008, p.114; Lucky, 2013, p.6). The zero-sum game and desperation of politicians soon became a thing and the politicians at this point were willing to do anything possible to get power and exercise control. Following this development, the citizens became weak as explained in Aristotle's argument cited in Ojo (2008, p.114) that when there is no strong middle class (like in the Nigerian state and the fact that the population existing in Nigeria are poor individuals), they will be unable to struggle and maintain balance in order to put the ruling class in check. After the independence and the discovery of oil in 1973, there was a massive influx of money in circulation, and only the rich were establishing political parties and ultimately got involved in politics (Ojo, 2008, p.114; Lucky, 2013, p.6). The implication of this was that the Nigerian poor citizens were reduced to onlookers and instruments, used in achieving the political ambition of the rich.

Thereafter, with the money made by government contractors after the discovery of oil in Nigeria, combined with the money stolen by military men who later became civilian politicians, money politics and election gifting became a thing in Nigerian elections. This was from the second republic to the present day fourth republic, with poor people remaining victims of the sour history (Ojo, 2008, p.113; Lucky, 2013, p.6; Sha, 2008, p.123).

\section{Predisposing Factors Leading to Election Gifting in Nigeria}

Many theories and concepts have been developed in the literature to explain the factors leading to election gifting in Nigeria. This paper will be examining some of the theories with analysis to explain the extent and scope of its existence in the Nigerian polity.

1. Lack of Planned Manifesto: To start with, giving a manifesto would mean that a particular ideology already exists within a political party. However, such ideologies that would lead to a well-planned manifesto do not exist in Nigeria. And even when they do exist, party members have little or no ideas of what their party stands for to enable them use such ideas in winning the conscience of voters. Ojo (2008, p.118) laments that it is embarrassing when candidates of political parties in Nigeria cannot engage in issues affecting the people. This argument was supported by A.E Davis (2003) and cited in Ojo (2008, p.118). It emphasizes that such attitude in a democracy shows incompetence and does not give citizens the opportunity to make rational choices among parties and candidates. This is because there is no political basis to use in discerning the better choice.

2. Political Cynicism: Ayoade (2006, p.2) argues that the lost hope of the people as a result of failed promises by the recent and past governments, lure citizens to settle for election gifts because they presume that it is the only 
way they can get the dividends of democracy. Ojo (2008, p.118) succinctly explained that when voters do this it simply means that they are asking for payoffs. Thereafter, they make the politicians justified in robbing the people of their commonwealth. In the same vein, the candidate engages in election gifting as an investment against electoral failure, which explains the gap between true democracy and the defect hybrid we have in Nigeria.

3. Illiteracy: This has been one of the most decaying factors affecting the Nigerian state from the beginning of our history. Danjibo and Oladeji (2007, p.196) argues that the lack of quality education in Nigeria has continued to turn the odds of good governance against us when it comes to electing leaders. The community of voters as a result of not being literate either does not understand what to expect from a political candidate, or they simply do not care about the consequences of their choices in the ballot box. The implication of this has resulted to unqualified and undeserving individuals getting into the position of power with little or nothing to offer. Furthermore, sharing gifts to the people during election period becomes a business they engage in before and during elections, which they see as a return of their initial investment when they get into power.

4. Poverty: Danjibo and Oladeji (2007, p.196) argue that poverty makes the people weak and easily susceptible to political manipulation. Ojo (2008, p.119) further extends this argument that people who are poor, and whose next meals are not guaranteed can easily sell their conscience/votes by receiving gifts from politicians in return for their support.

5. Lack of Effective Legislation and Strict Adherence to the Rules of the Game: Fortes and Pritchard (1950, p.4-5) argued in their edited book that rules in African countries are not generally applied. However, after many legislation and agitation about this problem in the academia, little or nothing has been done about it. Danjibo and Oladeji (2007, p.197) and Ojo (2008,p.119) argued that in order to check this problem, legislation has been provided in the 1999 constitution to regulate the activities of parties when it comes to party financing, especially during election. More so, with evidence of how money is spent and its continued influence in the election processes up to the 2015 election, there is no doubt that the implementation of such legislation is only in theory.

\section{Conclusion and Recommendations}

The community of voters irrespective of the justifications given is a part of the democratic problems bedeviling the Nigerian state. The prevalence of election gifting, being a dominant part of the democratic process, gives the politicians a moral ground to rob the people off their commonwealth. This paper takes a bold step to challenge the voting community, by showing them how the consequences of their non-evaluative and clientelist approach to 
democracy are the reasons for the sad realities in the Nigerian state. Furthermore, the 2015 presidential election serves "to some extent", as a reference point to show how the Nigerian voting community, took into cognizance the issues affecting the Nigerian people, and not only focus on the unsustainable election gifts shared by politicians during the election period. In order to sustain this development, this paper argues that compromise and sentiments do not need to be made in subsequent years of electoral processes in Nigeria. This paper has shown how election gifting comes back to hunt the people, as politicians use it as a yardstick to rob the people off their commonwealth. Therefore, it is better for Nigerians to do away with election gifting and be more conscious in the democratic business of electioneering. They should do away with it as a pathway to restoring the nation.

This paper opines that it is long overdue for the Nigerian state to organize itself massively through the formation of civil societies. This can be done with multiple platforms existing in the world today such as: the social media, trade unions, labour unions, social movements, and interest groups. The reality is that illiteracy can no longer be said to be a setback in the struggle for good governance, as its opposite is bad governance, which breeds hardship, and is suffered by all irrespective of their level of education. Dahl (1998, p.39) argued that democracy functions even better when the people who know things educate those who do not know, which in all allows everyone to participate with the knowledge required in the democratic process.

Finally, this paper calls for the massive engagement of civil societies, especially in the wake of the 2019 elections, where the temptation of election gifting will be available again. Civil societies in all spheres and platforms should help orientate the people on the dangers of limiting their legitimacy by engaging in election gifting. The people should rather strengthen their voice in every electoral process by voting for the best candidate who understands the issues and problems of the state, and as well has the capacity to deliver the true dividends of democracy (Statement of the Joint NDI/IRI Pre-Election Assessment Mission to Nigeria, 2018, p.8).

\section{References:}

1. Abutu, PO. \& Samsu, K.H.K. (2017). 2015 Presidential Election in Nigeria: Reasons Why Incumbent President Goodluck Jonathan Lost to Buhari. In IOSR Journal of Business and Management 19 (5), 132141.

2. Adeolu, D. (2015). Nigeria's 2015 Presidential Election: Between Democratic Consolidation and Change. In European Scientific Journal. 11(19).

3. Alapiki, H.E. (2004). Politics and Governance in Nigeria. Port Harcourt: Amethyst and Colleagues Publishers. 
4. Alemika, E.E.O. (2007). Quality of Elections, Satisfaction with Democracy and Political Trust in Africa. In Afrobarometer Working Papers. No 84.

5. Amadi, L.A. (2012). Democracy, Civil Society and Mass Action in Nigeria: A Case of Imo State General Elections 2011. In Pakistan Journal of Social Sciences. 9(1), 9-22.

6. Animashaun, M.A. (2015). Nigeria 2015 Presidential Election: The Votes, The Fears and the Regime Change. In Journal of African Elections. 14 (2), 186-212.

7. Araba, A. A. \& Braimah, J.O. (2015). Comparative Study of 2011 and 2015 Presidential Elections in Nigeria. Available online at https://globaljournals.org/GJHSS_Volume15/4- Comparative-Studyof-2011.pdf.

8. Ayoade, J.A.A. (2006). Campaign Abuses: Experience from the 2003 Elections. In IFES Nigerian Political Finance Newsletter. 4, 2-3.

9. Babatunde, O. (2015). 2015 General Elections and the Role of INEC. Available online at http://www.inecnigeria.org/wpcontent/uploads/2015/07/Conference-Paper-by-Tu ndeOyekanmi.pdf.

10. Bratton, M. (2008). Vote Buying and Violence in Nigerian Election Campaigns. In Afro-Barometer Working Paper 99.

11. Dahl, R.A. (1998). On Democracy. New Haven, London. Yale University Press.

12. Deji, A. (2013). Historical Background of Nigerian politics 19001960. In IOSR Journal of Humanities and Social Sciences. 16(2), 8494.

13. Diamond, L. (1994). Rethinking Civil Society towards Democratic Consolidation. In Journal of Democracy. 5(3), 4-17.

14. Danjibo, N.D. \& Oladeji, A. (2007). Vote Buying in Nigeria: An assessment of the 2007 General Elections. In Journal of African Elections. 6 (2), 180-200.

15. Fortes, N. \& Pritchard, E. (1950). African Political Systems. International African Institute London: Oxford University Press.

16. Huntington, S. (2016). Will More Countries Become Democratic? In Political Science Quarterly. 131 (2), 237-266.

17. Inokoba, PK. \& Kumokor, I. (2011). Electoral Crisis, Governance and Democratic Consolidation in Nigeria. In Journal of Social Sciences. 27, (2), 139-148.

18. Nichter, S. (2014). Conceptualizing Vote Buying. In Journal of Electoral Studies. (35), 315-327. 
19. Norris, P. (2008). Democratic Indicators and Trends. In Driving Democracy: Do Power-Sharing Institutions Work? Cambridge: Cambridge University. (pp. 54-78).

20. Obasanjo, O. (2005). Political Party Finance Handbook Independent Electoral Commission (INEC) Abuja.

21. Obasanjo, O. \& Mabogunje, A. (1992). Elements of Democracy. Abeokuta: ALF Publications.

22. Ojo, E. (2008). Vote Buying in Nigeria. In Money and Politics in Nigeria. Abuja: Petra Digital Press. Pp.109-122.

23. Onapajo, H. (2015). How Credible were the Nigerian 2015 General Elections? An "Electoral Integrity" Framework of Analysis. Paper presented at the International Conference on the 2015 Nigerian Election, organized by the Electoral Institute (TEI) of INEC, TEI Office, Abuja, Nigeria, 27-29 July, 2016.

24. Lucky, O. (2013). Money politics and vote buying in Nigeria. In Afro Asian journal of social sciences. 4(4.3), 1-19.

25. Procter, P. (1978). Longman dictionary of contemporary English. Harlow England: Longman.

26. Rothstein, BO. (2013). The Three Worlds of Governance: Arguments for a Parsimonious Theory of Quality of Government. In University of Gothenburg Quality of Government Institute. Working Paper Series 2013:12.

27. Said, A. (1997). The two Political Parties and the Electoral Process in Nigeria: $\quad$ 1989-1993. In Georges Nzongola-Ntalaja \& M.C Lee (eds), The State and Democracy in Africa. Harare: AAPS Books. Pp 126-140.

28. Schaffer, F. (2002). What is Vote Buying: Paper delivered at Trading Political Right, the Comparative Politics of Vote Buying, International Conference Center for International Studies. MIT, Cambridge, August 26-27, 2002.

29. Schaffer, F. \& Schedler, A. (2005). What is Vote Buying? The Limits of the Market Model. Paper delivered at the conference "Poverty, Democracy and Clientelism: The Political Economy of Vote Buying" Stanford University, Department of Political Science, Bellagio Center, Rockefeller Foundation, 28 November-2December 2005.

30. Sha, P. (2008). Vote Buying and the quality of Democracy. In Money and Politics in Nigeria. Abuja: Petra Digital Press.

31. Statement of the Joint NDI/IRI Pre-Election Assessment Mission to Nigeria. July 20 (2018).

32. Udu, L.E. (2015). INEC and the 2015 General Elections in Nigeria: Matters Arising.

In Research on Humanities and Social Sciences.

(5), 12. 
33. Ugoh, C. (2004). Electoral malpractices and violence in the 2003 general elections in Nigeria. In Unilag Journal of Politics, 1(1), 164186. 